\title{
The internationalization theory of the
} multinational enterprise: past, present and future

Article

Accepted Version

Buckley, P. J. and Casson, M. (2020) The internationalization theory of the multinational enterprise: past, present and future. British Journal of Management, 31 (2). pp. 239-252. ISSN 1467-8551 doi: https://doi.org/10.1111/1467-8551.12344 Available at https://centaur.reading.ac.uk/81900/

It is advisable to refer to the publisher's version if you intend to cite from the work. See Guidance on citing.

To link to this article DOI: http://dx.doi.org/10.1111/1467-8551.12344

Publisher: Wiley

All outputs in CentAUR are protected by Intellectual Property Rights law, including copyright law. Copyright and IPR is retained by the creators or other copyright holders. Terms and conditions for use of this material are defined in the End User Agreement.

www.reading.ac.uk/centaur

\section{CentAUR}


Central Archive at the University of Reading

Reading's research outputs online 


\section{THE INTERNALISATION THEORY OF THE MULTINATIONAL ENTERPRISE: PAST, PRESENT AND FUTURE}

\section{Introduction}

International Business (IB) is an inherently complex subject because of its global context, the importance of innovation, and the range of ownership and location factors that need to be examined. Here it is argued that IB theory can learn from economics, but that it should not emulate economics too closely because economics makes restrictive assumptions that assume away important issues in IB. We argue that better IB theory can be created by extending existing theories rather than by starting again with new kinds of theory. However, existing theories need to be formulated in a more explicit manner in order to increase their predictive power. More attention needs to be given to the role of the entrepreneur and the headquarters function. More emphasis also needs to be placed on the industry rather than the firm, so that competition and co-operation between firms can be better understood. The approach is pragmatic and constructive. It not only sets out how IB theory can be extended, but explains exactly how it can be done.

This paper thus presents an agenda for extending the internalisation theory of the multinational enterprise (MNE) in order to explain a wider range of international business phenomena. Some aspects of International Business have been studied exhaustively over the past decades - e.g. the market entry decision (Buckley \& Casson, 1998b; Dunning, 1977; Dunning \& Lundan, 2008), the role of subsidiaries (Rugman \& Verbeke, 2001) and the location of headquarters (Menz, Kunisch \& Collis, 2015, Kunisch, Menz \& Ambos, 2015) - but others - e.g. oligopolistic rivalry and the functions of MNE headquarters - have received relatively little attention. The theory needs to be extended to explore these neglected areas more thoroughly (Buckley, Doh \& Benischke 2017).

The structure of this paper is as follows. The following part examines the contribution of internalisation theory to international business. Section 3 presents some criteria for good theory. It 
critically examines existing IB theory and argues that much of it lacks predictive power. Section 4 examines the limitations of current theory, especially in relation to recent developments in the global economy. The fifth part suggests future theoretical developments to encompass these developments. The conclusion includes a research agenda.

\section{The contribution of internalisation theory to international business}

Classic internalisation theory (Coase, 1937) says that, conditional on location factors, multinational enterprises (MNEs) emerge when the benefits of internalisation exceed the costs (Williamson, 1975; McManus, 1973, 1975; Hennart, 1982; Rugman, 1981). As it stands, this is almost tautological. When a firm is found to an MNE, it is claimed that the net benefit of internalisation is positive, and if it is not an MNE then it is claimed that the net benefit is negative. But internalisation theory contains other propositions too, and it is the synergy between all these propositions that gives the theory explanatory power (Buckley \& Casson, 1976, 1985, 2009; Casson, 2014). Adding the proposition 'proprietary knowledge incurs heavy licensing costs that can be avoided by internalisation' enables the deduction from the theory that multinationality will be most common in knowledge-intensive industries, and the evidence will show this to be correct (Hymer, 1976). To develop the theory further, we can add 'the benefits of internalising knowledge are particularly high when intellectual property rights (IPR) are weak'. This predicts that in knowledge-intensive industries foreign direct investment (FDI) will be most common in countries with weak IPR, and licensing most common in countries with strong IPR, and again this is (mostly) right (Casson, 2000). To refine the theory additional factors can be identified, e.g. 'local entrepreneurial capabilities' to further increase explanatory power (Buckley \& Casson, 1998a).

Internalisation theory not only explains what will happen; it explains what will not happen too. Internalisation assumes that firms maximise profit. Managers do not make irrational decisions that damage the interests of the shareholders. This implies, for example, that firms do not internalise 
organised commodity futures markets, except at times of panic or crisis, because it would be inefficient to do so.

The assumption that drives these strong results is often questioned (Buckley, Devinney \& Louviere, 2007). Are managers really rational, and do they always put shareholders' interests first? This does not accord with empirical observation. So we can assume that they can be irrational and dishonest. Irrationality can take many forms, and so can dishonesty. So managers can now do almost anything. They could even act rationality, but only by accident or mistake. The theory has degenerated into a tautology. It says, in effect that 'managers do whatever managers do'. The theory is more realistic but is not a predictive theory any more.

The theory can be rescued, but it requires some effort. Suppose we observe an irrational bias to internalisation. Perhaps managers believe they are rewarded by the size of the firm as well as profitability. Thus they have a bias to internalise because it increases firm size and boosts their salaries. shareholders will not necessarily lose. If shareholders believe that bigger firms are more attractive to institutional investors, then growth through internalisation may increase the equity price and afford the shareholders capital gains, which could exceed their temporary loss of profit. The theory can therefore remain predictive if we change the assumptions. We assume that managers maximise shareholder value rather than profit, that value depends upon size, and that size affects salaries. All of these are testable propositions. Rationality still prevails, but in a wider context than before. We have not rejected the key assumption, but rather refined it, by replacing profit with shareholder value. We have rescued the theory and avoided tautology.

\section{By what standards should a social science of international business be judged?}

\subsection{Explicit assumptions}


The origins of internalisation theory lie in economics. In economics, assumptions are made explicit. They are combined with each other, and hypotheses are derived by logical deduction. This logical process gives the theory a transparency which other types of IB theory often lack. Transparency makes logical error easy to expose. Economic theory can derive an entire set of hypotheses from a single set of assumptions. Internalisation theory, for example, explains both horizontal and vertical integration by an MNE.

The use of a common set of assumptions for different hypotheses ensures that these hypotheses are logically consistent. It is easy to criticise the assumptions of economics because they are so explicit. It is harder to criticise the assumptions of other IB theories because they are often implicit. Furthermore, many hypotheses in IB are derived from a synthesis of the literature, and embody different assumptions made by different authors. There is no guarantee that hypotheses derived in this way are mutually consistent.

\subsection{Using mathematics to achieve clarity}

Economic theories are often presented in a formal, even mathematical, way. This is sometimes regarded as an obstacle to understanding, but mathematics often provides clarity. The global economy is intrinsically complex, and IB studies is therefore complex too. Ownership, location, exporting, direct investment, licensing, competition and co-operation all have to be considered at the same time. Simple theories inevitably over-simplify, and distort reality as a result. As theory becomes more complex, it becomes increasingly difficult to follow a purely verbal exposition. Mathematics addresses complexity directly by replacing words with symbols and sentences with equations. This makes the logical structure clear. Using mathematical notation, a complex theory can be just as easy to understand as a simple one. Although the number of factors changes, the mathematical structure does not. Other branches of social science have developed sophisticated mathematical models, and there is no insuperable reason why IB studies cannot do the same. IB theorists have not been particularly 
ambitious in this respect, however. They need to be more ambitious if IB theory is to realise its full potential.

\subsection{Developing a logical structure in theorising}

The typical structure of sophisticated social science theory is outlined below. It is illustrated with practical examples from IB

Unit of analysis. A key type of actor is identified (e.g. individual, firm, nation state). The actor is usually a ‘decision-maker' who owns and controls some resources (Buckley \& Lessard, 2005). The number of actors is specified (e.g. the number of firms in an industry, the number of subsidiaries in a firm)

The objectives of each actor are specified (e.g. to maximise the value of some performance measure, such as productivity, profit, market share or growth rate).

Each actor has a specific set of actions they can perform (e.g. alternative activities to which they can allocate their resources). Some actors may have a wider range of opportunities than others; this is determined by their access to resources, and by other individual characteristics (e.g. reputable firms with strong brand identities have greater access to finance).

The nature of the environment is described. There are two aspects of this: the physical environment and the knowledge environment. In firm-level studies the physical environment typically comprises the world and its resources, while in managerial micro-studies it may be the firm itself, or even one of its subsidiaries, or the people working in them. The knowledge environment is only implicit in many theories, and has not received the attention it deserves (Richardson, 1998). In a global context it comprises the set of all recorded evidence and the set of all concepts and theories available to analyse them. In IB the knowledge environment is usually discussed in the context of the individual firm, 
where the focus is on the set of existing technologies available to the firm, together with new technologies that it is capable of developing.

The structure of the environment is specified. The physical environment may be divided into subunits. In IB geographical sub-divisions are naturally prominent, e.g. different nation states. Different types of product are also distinguished, e.g. different industries, and also different functions, e.g. production, marketing and R\&D. Relations between sub-units may be specified, e.g. distances between geographical sub-units, substitutability and complementarity between products, and interdependencies between functional areas. The knowledge environment is structured in many different ways, e.g. theories, documents and data in different subject areas, some of which are relevant to IB and others not.

Exogenous factors which govern the environment are itemised. These are typically the key factors to which actors respond (e.g. taxes, tariffs, product demand). The values of these factors may vary across sub-units (e.g. local demand, institutional environment and local resource availability in each nation state). With $M$ general factors and $N$ sub-units there are $M N$ factors altogether. Exogenous factors driving change in the knowledge environment include scientific progress and cultural trends.

Allowance is made for diversity of institutions. Deeg and Jackson (2008) make the point that the view of institutions in IB general is "thin", relying on numerical average or summary indicators rather than thick description. The diversity of institutional landscapes would, in their view, allow richer theorising. This is certainly a promising direction of international business theorising giving much more heft to the external environment as a key determinant of internationalisation, internalisation and other strategic decisions of MNEs.

Behaviour. Each actor selects a particular action to perform (e.g. innovate, invest in a location). These actions are endogenous because they respond to the environmental factors (e.g. location is influenced by tariffs). Actors may also respond to the actions of others (e.g. an established firm may respond to 
the entry of rivals by cutting price). The response of each actor is mediated by their objectives, resources and other characteristics (e.g. a firm's response to investment opportunities is determined by its objectives, e.g. profit, growth, its resources, e.g. its technological capabilities, and other characteristics, such as whether or not it is family-controlled).

Distributed actions. Each actor may perform a different action in each sub-unit (e.g. a firm may licence in one market but undertake FDI in another). Behaviour in each sub-unit may respond only to local factors, or to factors elsewhere in the environment too (e.g. a firm may not license in one market because it fears that the licensee will export to a neighbouring market in which the firm has already invested).

Outcomes. A set of actions, when performed in a given environment, results in a set of outcomes (e.g. prices, profits). Different outcomes are of concern to different actors (e.g. each firm's profit is mainly of concern to its own managers and shareholders). Some outcomes are public knowledge (e.g. the published profits of rival firms) whereas other outcomes are known only to those who are affected by them (e.g. sales revenue generated by a firm's specific products).

Equilibrium. At the time an actor makes a decision they may have a definite expectation of what the outcome of that decision and its consequences will be. After the decision has been made, the outcome will be observed, and the actor can then compare the expected outcome with the actual outcome. If they are the same then the actor is said to be in equilibrium, since there is no reason why they would wish to have changed their decision, given the state of the environment and decisions made by other actors. If every actor is in equilibrium then the system is in equilibrium.

Feedback and learning. If the actual outcome differs from the expected outcome, however, then the actor must decide whether this is the result of an unpredictable random fluctuation, in which case they may not want to change their decision, or the consequence of some limitation of their judgement, such as lack of information or bad theory. They may investigate the outcome further order in order to learn 
from their mistake (e.g. when sales are higher or lower than anticipated). The incentive to learn is greatest when a serious mistake has been made. Learning from mistakes augments the future stock of knowledge and so modifies future behaviour (e.g. if sales are unexpectedly low advertising budgets may be increased). Behaviour therefore evolves over time.

Measurement. Endogenous decisions and exogenous factors are typically represented by the values of various categorical, binary, discrete, or continuous positive variables (e.g. sales and profits are continuous variables, industry is a categorical variable, and family control is a binary variable).

\subsection{Current Issues in IB theory}

This discussion so far may be summarised as follows.

There is too little emphasis on the individual and too much on the firm.

There is too much emphasis on the single representative actor, operating in isolation, whether they are an individual or a firm. Conversely, there is too little emphasis on interactions between actors, such as networking between individuals or competition and co-operation between firms.

The objectives of actors are often fuzzy. Without a clear statement of actors' objectives it is difficult to relate their behaviour to the environment. This vital link in theorising is often weak.

The global environment of IB activity needs to be spelled out much more clearly and systematically. More attention needs to be given to the specific factors that impact on actor's behaviour, and how these factors can be measured accurately.

The issue of learning needs to be taken more seriously. While equilibrium models are rightly criticised for ignoring learning, nothing much has so far been learned from theories of learning because most of these theories lack predictive power.

\section{What are the outstanding theoretical problems in international business?}


The theory still, at least implicitly, relates to manufacturing industry. Services have become increasingly tradeable, not only because of their embodiment in physical products (products as a mobile store of future services (Casson 1990 p 2)) but also because of the movement of people (leisure services, medical care) and trade via telecommunications and the internet.

The focus on a single market - most obviously in high tech products - is limiting. Internalisation of markets in semi-processed inputs, components and information requires a focus on multiple markets The focus on a single firm (Hennart 2009) is unwarranted. This requires widening the theory to a system-wide perspective. Boundaries of firms often abut one another and thus rival multinationals compete, often in a pre-emptive internalisation strategy for key activities. Joint ownership in alliances and joint ventures may be an optimal outcome or competition, direct or through a third party thus raise complex strategic questions, understandable only at the system level.

Leading from the previous point, a polarised view of contractual arrangements - contrasting pure arm's length trade with hierarchy - is unjustifiable in the modern world economy. The theory needs to include social as well as legal aspects of contracts to encompass the complexity of quasi-integration. The theory remains unduly static when competitive advantage is taken as fixed. The evolution of the global system is continuous and does not simply move from one static equilibrium to another. In internalisation theory the behaviour of the firm is endogenous, while the environment of the firm is exogenous (Coase, 1937). The theory generates hypotheses, linking endogenous behaviour of firms to the exogenous business environment. The link depends on the profit assumption (or an equivalent), which is key (Casson, 1996, 2014).

The theory manifests contingency. If a firm is knowledge-intensive it is more likely to be an MNE; if it not, it is less likely to be an MNE. Changes in the contingent factors change the behaviour of the firm. If IPR is strengthened over time then internalisation decreases. If the IPR regime is stronger in one country than another then licensing is more common in that country (Buckley \& Casson, 2011). 
Contingent factors explain historical variations. Some forms of MNE, such as free-standing firms, which do not trade in their headquarters country, are not so common today as they were in the nineteenth-century (Wilkins, 1988). Conversely, horizontally-integrated market-seeking firms were not so common in the nineteenth century as they are today (Dunning, 1983).This is because global production has shifted from commodities to manufactured products. The theory is not completely static, therefore. It can address dynamic issues. It portrays behavioural change as adaptive: it explains changes in behaviour as a rational response to a changing environment. Building in contingency adds robustness to the theory.

A good theory is a general theory. The theory does not have to change every time circumstances change. A general theory sets out many possible states, such as different configurations of the MNE, and shows that in different environments different configurations emerge. The theory may encompass many possibilities that appear absurd. The theorist may be criticised for even mentioning them. But if circumstances change in a radical way then 'absurdities' suddenly become practical possibilities.

Likewise many familiar configurations may disappear. The twentieth-century MNE was very different from the nineteenth-century MNE and the twenty-first-century MNE may well be different from both. The theory must be sufficiently general to include the unthinkable as a logical possibility, so that when it occurs it can be properly understood (Casson, 2005; Casson, Dark \& Gulamhussen, 2009).

\subsection{Distinctive features of IB as a subject area}

'If advances in IB theory were easy they would have been made already.' There is some truth in this remark, but it is not completely correct. IB could have made more use of mathematical theory, as noted above. It could follow early IB theorists, and import ideas from economics, but instead, for the last thirty years, it has imported ideas from strategy instead (Barney, Wright \& Ketchen, 2001; Cantwell, 2014; Porter, 1980; Rugman \& Verbeke, 2003; Dunning, 1993). But direct emulation of economics would have been a mistake. IB has a number of distinctive features which mean that 
economic theories must be modified before they can be imported into IB (Robbins, 1932; Samuelson, 1947; Richardson, 1964; Casson \& Wadeson, 2012).

Heterogeneity of the principal actors. In many economic models, all the leading actors, such as individuals or firms, are the same (Penrose, 1959). The entire analysis is conducted in terms of a representative consumer or a representative firm. Pairwise relations between representative agents are then scaled up to theorise about the economy as a whole. But in IB the leading actors are heterogeneous (Buckley \& Lessard, 2005). Every MNE is different, because each technology is different, the entrepreneurs are different, and key characteristics, such as headquarters location, are different too. It is these differences make IB a fascinating subject. But they also pose a challenge. Industry analysis with homogeneous firms is quite challenging, as economic theory makes clear, and industry analysis with heterogeneous firm is even more so. Nevertheless, progress is possible, as explained below (Beugelsdijk, van Ees, Garretson, 2014).

Complexity of the physical environment. The global economy is an extremely complex system (Krugman, 1991; Markusen, 2002). Economic theories are still formulated mainly at the level of the nation state. This is partly a legacy of the nineteenth century; Marshallian economics developed when European nation-building was at its height, and there has been little fundamental change since then. The global economy is the province of international trade theory, migration theory, and other specialised sub-fields; it does not occupy the central place in economics that it does in IB theory. There are theoretical reasons, as well as practical reasons, for focusing on the global economy. The global economy is a closed system, whereas a national economy is an open system. The national economy trades with other nations but the global economy is largely self-contained. As such, it satisfies internal conservation laws, e.g. total imports equal total exports, and total outward investment equals total inward investment. When formulated at a global level, IB theory must satisfy these laws, and this provide a valuable check on consistency (Buckley \& Hashai, 2004). 
Importance of the knowledge environment. The crucial role of innovation in IB means that the knowledge environment is far more important than in conventional economics, where the nature of the product usually remain fixed over time. Furthermore, knowledge is distributed over space, e.g. knowledge of all kinds tends to be clustered in specialised hubs based in major cities and regions. Customer perceptions of products are also influenced by local knowledge encoded in customs and traditions.

Successful innovation requires good judgement, which must be supplied by the innovating entrepreneur. The entrepreneur's job is to collect as much information as they can, including confidential information obtained through business and professional networks, and to interpret this information in the light of their previous experience. For this purpose they may employ simple heuristics rather than rational calculation. Theorising is difficult because an individual's choice of heuristics depends on a range of personal and social factors that remain poorly understood (Casson, 1997).

Granstrand (1998, p 465) explicitly links "the idiosyncrasies of technology (i.e. technical competence)" to management. "In particular, a technology-based firm tends to engage in technology diversification, thereby becoming multi-technological". This suggests that theory can develop by analogy to product diversification as strategic decisions of MNEs, as demonstrated by Penrose (1959). An exciting extension of the theory might then be to model the implications of multi-technological firms along the lines of Buckley and Casson's (2007) interpretation of the growth dynamics of Penrosian product diversification

Importance of learning. In many economic theories interaction is instantaneous. In Marshallian market theory, for example, prices are negotiated instantaneously so that all trade takes place at equilibrium prices. In practice, however, interactions take time. Markets adjust through inventory changes and slack in capacity, as well as through price. People learn slowly and modify their behaviour 
accordingly. Technologies are improved through feedback from production experience. Policies change when politicians learn from their mistakes.

Learning is a complex process, however. People constantly update their memory by adding new information, but they discard information too. Learning itself may be regarded a rational process that optimises performance when information is costly: patterns are inferred from correlations, and causation is imputed (rightly or wrongly) from leads and lags. Another approach is through heuristics; these are behavioural rules, often based on intuition, which are up-dated in the light of experience. The study of entrepreneurial heuristics could be a useful starting point in developing a predictive theory of learning that is relevant to IB.

\subsection{The need to extend the range of topics addressed}

Internalisation theory was developed to explain two key phenomena of the 1970s: namely the concentration of FDI in knowledge-intensive industries and the cross-flow of FDI between the US and Europe. Neither could be explained using conventional economic theory. There were anomalies that had to be addressed. The theory was designed for this specific purpose.

Because it was based on a fundamental principle, however, it was readily generalised. The early focus on Western MNEs was broadened. It has been claimed, at various times, that internalisation theory cannot explain Japanese MNEs, Chinese MNEs (Buckley, Clegg, Cross, Zheng, Voss \& Xin Liu 2007), and other emerging market MNEs, but it has since been shown that the theory applies to MNEs wherever they are headquartered (Ramamurti \& Singh 2009; Ramamurti, 2012; Hoskisson, Wright, Filatotchev, \& Peng, 2013) . It is a general theory that develops contingent predictions, as explained above, and it is this contingency - allowing for different forms of MNE to emerge in different contexts - that gives it such flexibility (Buckley \& Ghauri, 2004, Buckley, 2007, 2009(a), 2010, 2011(a) (b), 2012, Buckley \& Strange, 2015). 
Internalisation theory covers 'market-seeking', 'resource seeking' and 'efficiency-seeking' MNEs (Dunning, 1958). It has been integrated into 'new trade theory' to explain global patterns of trade and FDI in differentiated products. It also explains patterns of intra-firm trade in intermediate products. Most recently it has been used to analyse global value chains and the 'global factory' (Rugman \& D’Cruz, 2000, Buckley \& Ghauri, 2004, Buckley, 2011b, 2012).

It also explains anomalies in business history. As noted earlier, nineteenth-century MNEs used organisational forms that are unfamiliar (though not unknown) today. Internalisation theory accounts for these forms by recognising the advantages of separating legal and administrative headquarters, as noted above (Casson, 2016).

The internet and the world wide web have had an enormous impact on global business, and social life in general, but little research has been published on the internet in IB journals. There have been two special issues of JIBS, which were fifteen years apart, in 2001 and 2016, and very few other papers. Most papers treat the internet and web as part of the environment of business rather than as business operations themselves. Instead of analysing innovation by internet MNEs, and exploring their internalisation strategies, these papers examine the impact of the internet on the boundaries of conventional MNEs. Verizon, for example, which is a large MNE formed by the merger of GTE and Bell Atlantic in 2000, has been mentioned only once in JIBS, and then only in a list of the top 25 regional MNEs in 2004 (Oxley and Yeung, 2001; Leamer and Stoper, 2001; Brouthers, Geisser and Rotlauf, 2016; Chen and Kamal, 2016; Rugman and Verbeke, 2004).

The internet, as its name indicates, is part of a networked ICT industry. There is functional specialisation between infrastructure owners (both cable and wireless) and customer-facing service suppliers (internet service providers, ISPs) who generate traffic. There are virtual ISPs who hire capacity from other ISPs, and specialist facilities firms that host co-located servers. The system has a 'hub and spoke' configuration, comprising trunk lines and local feeders, with some firms combining end-on links to connect up distant cities. There is price competition between firms that control 
alternative routes. Cartels and mergers can stifle competition, however, when a single firm, or group of firms, owns and controls all the fastest routes.

The boundaries of internet firms is recognised as a crucial issue by the UN-based International Telecommunications Union, the Internet Society and other non-profit associations, yet there is very little analysis of it within IB. It seems to be assumed, at least implicitly, that such analysis is the province of ICT specialists alone. There is more IB research on the use of the web for marketing, but even here the internalisation strategies of search engine proprietors, social network sites, mail-box providers and internet service providers have not been fully investigated.

It could be argued that the complexity of ICT networks is a deterrent to research, and that the firms involved are secretive. But major insights can be gained by using simple metaphors. The railway system is often described as the 'Victorian internet', while the web is likened to a virtual market place. These metaphors work extremely well. The railway system, like the internet, was a network that speeded up communication; it combined infrastructure with traffic generation, and integration (i.e. common ownership) between the two. Likewise conventional urban markets involve private retailers supervised by local councils and government officials just as the web resembles a global market place with private web sites overseen by non-profit international associations.

\section{Extending Internalisation Theory - How improvements can be effected}

\subsection{Three key steps; the entrepreneur, headquarters functions and industry level analysis}

The first step should be to clarify the role of the entrepreneur. This will rehabilitate the individual actor in IB, and counter the corporatist approach that now dominates so much of the literature.

The second step should be to examine in depth the headquarters functions of the firm. An entrepreneur can, in principle, be supported by a management team distributed over different locations. Headquarters has too long been regarded as a unitary activity with a fixed location. Evidence shows 
that different headquarters functions can be devolved, and possibly co-located with local production and marketing functions too. Despite recent progress in this field, more theorising needs to be done. The third step is to generalise classic internalisation theory from the firm level to the industry level. There is too much emphasis on a single firm studied in isolation, and too little emphasis on competition and co-operation between firms in an industry. While economists have analysed competition in detail, IB theorists have not. Early progress in IB oligopoly theory has not been followed up (Rowthorn \& Hymer, 1971; Knickerbocker, 1973; Graham, 1978). While co-operation has been analysed at the dyadic level, there has been only limited analysis at the industry level.

\subsection{The role of the entrepreneur}

Entrepreneurs have been defined as individuals who specialise in taking judgement decisions. A judgemental decision is one in which people cannot agree on what is the right decision (Knight, 1921; Kirzner, 1973). People cannot agree because they either possess different information, or interpret the same information in a different way, or a combination of the two. Entrepreneurs believe that they have an information advantage over others, and they exploit this advantage to identify new opportunities. It gives them the confidence to invest in new ventures that others would avoid. If they are correct in their beliefs they make a profit and if they are wrong then they make a loss.

Entrepreneurship was discussed as long ago as the eighteenth century, when the entrepreneur was described as an employer of labour (Casson, 1982). Directing employees is a special case of exercising judgement. The worker, it is assumed, does not know what consumers want; the entrepreneur believes they do know, but they lack the skill to produce it themselves. The entrepreneur therefore hires the worker, paying them what they could earn in their best alternative job (their reservation wage). The entrepreneur guarantees this wage to insure the worker against their own misjudgement. The wage is paid in advance of the sale of the product, so this investment is at risk. The entrepreneur accepts this risk because they are confident. They believe that they can charge more for the product than it costs to produce, and so they will make a profit. The worker signs a contract in which they forego their 
'natural right' to the product of their labour, and accept the direction of the employer over what they produce and how they produce it.

Entrepreneurs establish firms. A firm is a useful legal device for an entrepreneur, as it separates their business interests from their personal interests. A firm can provide limited liability and tax privileges. The entrepreneur intermediates between worker and customer. The firm acts as the nexus of the contracts. The entrepreneur appropriates a profit through the firm from the margin between the wage and the price. As a legal entity the firm can outlive the entrepreneur. For the business to survive and grow in a volatile environment, the entrepreneur's successors must adapt the business, responding creatively to new opportunities and threats. They too must be entrepreneurs.

Entrepreneurs not only create firms; they create markets as well. In economic theory the numbers of firms and markets are often taken as fixed, but in practice they change continually. Product innovation creates new markets, as new firms spring up to capitalise on the success of the innovator. Firms and markets are not exogenous therefore; they are the endogenous outcome of entrepreneurial activity. The entrepreneur is particularly important in IB theory because they take important decisions about the organisation of the MNE. Writing in the 1930s, Schumpeter (1934) identified organisational innovation as one of five main types of innovation. Schumpeter cited cartels as an example, but international cartels have been relatively unimportant post-1945. The MNE itself is an organisational innovation, but the MNE built on earlier organisational innovations, such as the 'modern corporation' of the 1920s, as described by Chandler (1962), which raised bureaucratic management techniques to new heights of sophistication. This involved reporting systems, accounting systems, and the mechanisation of the office through type-writers, duplicators and calculating machines, which in turn stimulated further innovations, such as the M-form multi-divisional firm, based on internal transfer pricing. It also created two contrasting management styles, the low-trust style based on explicit contracts, formal monitoring and high-powered pecuniary rewards, and the high-trust style based on implicit contracts, informal mentoring, lifetime employment and status-based rewards. By 1945 there 
was a repertoire of management models that firms could adopt, and entrepreneurs could choose between them.

The choice of organisational culture is an important entrepreneurial decision. It influences the costs of coordination in both internal and external markets. Relatively little is known about the costs and benefits of different cultures, except that they seem to vary considerably between industries. Knowledge-intensive industries often claim to possess a high-trust culture, but the sincerity of this claim is debatable. More research is definitely required.

\subsection{The headquarters function}

A large MNE has a legal headquarters, from which taxes are paid. It has shareholders who underwrite financially the strategic decisions of the entrepreneur, and therefore needs a financial headquarters. The firm also needs to control its subsidiaries and negotiate with its subcontractors, franchisees and licensees. For legal reasons the firm needs to be incorporated in a politically stable country with efficient and impartial legal institutions,; for financial reasons it needs representation in a major stock market where new shares can be issued and existing shares traded; and to coordinate its global activities it needs an operational headquarters at a communications hub (Bei \& Fageda, 2008; Buckley, 2011b).

In principle these different headquarters activities could be located in different places: the legal headquarters in a low-tax country, the financial headquarters close to a major stock market and the operational headquarters at centre of transport and communications networks.. There is also the question of where the entrepreneur themselves would like to live.

There are obvious advantages to co-location, and so locations that meet all four criteria - low-tax good-lifestyle well-connected financial centres - will attract co-located operations. A distributed headquarters may be useful, however, for specific purposes; thus a French-owned firm operating 
mainly in the British Empire might select Paris as its financial headquarters but London as its legal headquarters in order to gain political influence with the British state. The headquarters of a firm can therefore be distributed over different locations, and the locations chosen may reflect both the strategic requirements of the firm and the preferences of the entrepreneur.

\subsection{From firm-level analysis to industry-level analysis}

Firm-level analysis and industry-level analysis are often conflated in IB. The concept of ownership advantage or monopolistic advantage is sometimes invoked to suggest that an MNE has no competitor, so that firm and market are the same. This not usually the case, however. Most MNE face one or more competitors, and together they form the industry. Industry level analysis thus involves interactions between multiple firms. These interactions may be competitive or co-operative, or both. They may involve many firms or few firms.

Conventional economics emphasises perfect competition, which involves a large number of small firms. The theory was developed at the turn of the twentieth century, when small business was still dominant in industrialised economies (Backhouse, 1994). The theory merits careful study. It assumes that all firms produce the same homogeneous product. Because firms are small, each firm does not react to other firms individually, but to all other firms in the aggregate. The other firms all serve the same group of customers, and so competition between them determines a competitive price. If the individual firm entered this market its market share would be so small that it would not affect the price. The prevailing price is therefore the price that the firm would get if it entered the market. All interaction between firms can therefore be regarded as an interaction between each firm and the market price - a single statistic that is publicly known.

The rise of big business challenged this theory and led to the development of oligopoly theory. In oligopoly there are fewer firms in the industry, and the entry and exit of any firm can change the price. Each firm responds to each other firm individually. There is a problem, however: how can each firm 
know how the other will respond to them when they respond to it? There is no easy answer to this. There is a simple way of analysing the issue, however. This is to postulate a simple but unrealistic process that may mimic the outcome of a real and much messier process.

Oligopolistic strategy is, in practice, the responsibility of the entrepreneur. It is normally analysed using the theory of non-co-operative games. If a given entrepreneur knew the decisions already taken by all the other entrepreneurs then, given their knowledge of their own situation, the entrepreneur could choose their best response. For example, if they knew that everyone else planned to innovate they might anticipate that the market would be saturated and decide not to innovate themselves. On the other hand, if they knew that no-one else planned to innovate then they might decide to innovate because they could obtain a monopoly. In general they could calculate their best response to any combination of strategies by the others.

Suppose now that information about their responses was available to everyone else, so that everyone knew everyone else's responses to everyone else's moves. Two main possibilities now emerge (Fudenberg \& Tirole, 1991). Everyone could determine which sets of moves would leave everyone (including themselves) making their best response. These sets of moves would be common knowledge. Each set of would represent an equilibrium, because no entrepreneur would have any reason to regret their move. Suppose that there was a single such set of moves. This set could then become a 'focal point'; each entrepreneur would conjecture that the others will make their equilibrium moves, and so it would pay them to make their own equilibrium move as well. If there were several such sets of moves then there would be several focal points, however. If everyone benefited most from the same equilibrium than that could become the focal point, but otherwise conjectures could be incompatible. It can therefore be predicted that a unique equilibrium will generate a unique outcome, but multiple equilibria will normally not.

The other possibility is that the moves are made in sequence. This gives an advantage to early movers, because they can predict the responses of subsequent movers, and optimise their own move 
accordingly. The sequential approach always generates a unique equilibrium. But the question of who determines the sequence remains unresolved. One solution is to say that the most entrepreneurial person moves first, the second-most entrepreneurial moves second, and so on. But to have predictive power, each person's entrepreneurial ability must be determined from independent information and not just inferred from the sequence of moves.

Oligopoly theory is well suited to the analysis of innovation (Sanna-Randaccio \& Veugelers, 2007; Petit \& Sanna-Randaccio, 2000; Petit, Sanna-Randaccio \&Sestini, 2012). Each potential MNE is controlled by an entrepreneur who has discovered some new product or process and is deciding whether to commit to its exploitation. For each entrepreneur the profitability of innovation will depend on whether their rivals decide to innovate as well. The outcome can be predicted using the equilibrium concepts set out above.

Oligopoly theory can also be used to analyse co-operation (Buckley \& Casson, 1988, Axelrod, 1984). In this case entrepreneurs benefit when other entrepreneurs innovate too. Co-operation can be achieved either by conjecture or contract. Co-operation by conjecture is similar to competition in that each entrepreneur has to anticipate how the others will behave. Under competition, innovation strategy tends to follow the principle 'I will if you won't, and I won't if you will. I will go first, if I can, to discourage you from following'. But under co-operation by conjecture, entrepreneurs tend to follow the principle 'I will if you will; I won't if you won't. I will go first, if I can, to encourage you to follow'. Co-operation by contract, on the other hand, involves all the entrepreneurs 'sitting around the table' (either actually or metaphorically) and negotiating a single multi-lateral agreement. It can be analysed using the theory of co-operative games. Equilibrium requires that each party profit at least as much as they would from making no deal, or from negotiating a credible alternative deal of some kind, possibly with a sub-set of partners. In practice the entrepreneurs may form rival alliances which then compete against each other. The division of profit between rival alliances will be determined by impersonal competitive forces, as in the pure competitive theory, whilst the division of the profit within each alliance will be determined by contractual negotiations between the parties involved. 


\section{Conclusion and Research Agenda}

IB research has always focused on the firm (Hennart, 2009). Looking inside the firm reveals headquarters and subsidiaries. But headquarters is not unitary; it is a collection of functions, which can be separated. The key function is that of the entrepreneur, who until recently was almost entirely missing from IB theory. The entrepreneur is a real person, unlike the firm, which is a legal fiction. The firm, of course, has a management team, but this team is selected mainly by the entrepreneur.

Looking outside the firm reveals the environment. But the board room windows give a very parochial view. The key question is not how the board sees the environment but what the environment is actually like. The global environment is both large and complex, and is best observed with detachment by taking a 'bird's eye' view.

The inside and the outside of the firm are connected. The entrepreneur scans the environment for opportunities. Only when an opportunity has been discovered will the founder establish the firm. The firm is an instrument of value creation and appropriation and its organisation structure is designed by the entrepreneur with this in mind. Internalisation is only one of many issues that the entrepreneur must consider. Once they have invested in the firm (and persuaded others to do so too) competitive threats become a major issue. The entrepreneur cannot afford to view these threats as a vague attempt by hostile forces to undermine his 'ownership advantage'. The entrepreneur needs to identify specific potential entrants, and consider whether they can deter them, or mitigate the impact if they enter. In other words, the successful entrepreneur needs a 'bird's eye' view, and not a 'boardroom view', and this is the view provided by oligopoly theory.

The boardroom view must be understood for what it is: a myopic version of the bird's eye view. The bird's eye view is complex and sophisticated. It is rendered intelligible, not through oversimplification, but through clarification. Metaphors can be useful in discerning the structure of a system, but the underlying logical structure is often best revealed with the aid of some simple 
mathematics. What goes in inside the firm is indeed related to what goes on outside, but to understand the connections fully it is necessary to develop a rigorous theory of the global system as a whole. This is what many of the founders of IB theory set out to do. Progress has been made - but not far enough. Completing this mission is a worthwhile agenda for future IB theory.

The practical implications of expanding IB theory in the directions suggested focus managerial and entrepreneurial attention onto the external environment, particularly its risk profile, onto issues of delegation of authority from Headquarters and onto competitive strategies. Entrepreneurial and managerial judgement about the expansion of the boundaries of the firm - including alliances and takeovers, together with the risk and uncertainty faced in such expansions (or contractions) are areas in which theory can aid strategic decisions. The implications for firm structure are embedded in the role of Headquarters, their location and the division of managerial labour across the firm. Competitive strategies both with the industry and along value chains are practical outcomes of theory development, together with the links between competition, cooperation and innovation. Future theorising can also be a practical guide to strategy. Internalisation is not simply about 'make or buy'. Internalisation decisions can also be strategic weapons pre-empting or excluding competitors.

\section{Research Agenda}

A terse version of the research agenda that emerges from this analysis is the exploration of managerial behaviour in the internalisation theory context. This connects the sub-themes of this paper including the role of entrepreneurship over time as the firm emerges from the start-up stage to maturity, where internal entrepreneurs drive innovation, both in technology and in marketing and managerial practice (Casson, 1990, 2000). The HQ function has, with the exception of its location, been under-researched and its roles need to be deconstructed and examined. This would include complementarities between functions, externalisation of $\mathrm{HQ}$ functions and the locus of entrepreneurial decision making as the firm develops, recombines its activities and mutates into a network (Foss, 1977, Collis, Young \& Gould, 2007, Martin and Eisenhardt, 2010). The role of internalisation as a strategic weapon is also a fruitful 
area for future research, taking internalisation beyond the 'make or buy' decision to a comprehension of the role of replacing markets in order to pre-empt competitors. The inclusion of competition as a central focus of internalisation theory requires some theoretical realignment to the 'industry' or 'strategic group' level (Porter, 1980, Harrigan, 1985).

The resulting research agenda is dynamic, management-focused and allows meaningful engagement with cognate studies on entrepreneurship, business history and strategic management. In this way, internalisation theory becomes a central concept in a true social science of business strategy. 


\section{References}

Axelrod, R. (1984). The Evolution of Co-operation. New York: Basic Books.

Backhouse, R. (1994). New Perspectives in Economic Methodology. Routledge: London.

Barney, J., M. Wright, and D. J. Jr. Ketchen (2001). 'The resource-based view of the firm: Ten years after 1991', Journal of Management, 27, pp. 625-641.

Bei, G., and X. Fageda, (2008). 'Getting there fast: Globalisation, intercontinental flights and the location of headquarters', Journal of Economic Geography, 8, 4, pp. 471-495.

Beugelsdijk, S. B., H. van Ees, and H. Garretson (eds). (2014). Firms in the International Economy: Firm Heterogeneity meets International Business. Munich: CESifo Seminar series.

Brouthers, K.D., K. D. Geisser, and F. Rothlauf (2016). 'Explaining the internationalization of ibusiness firms', Journal of International Business Studies. 47, 5, pp. 563-576.

Buckley, P. J. (2007). 'The Strategy of Multinational Enterprises in the Light of the Rise of China', Scandinavian Journal of Management, 23, 2, pp. 107 - 126.

Buckley, P. J. (2009a). 'The impact of the global factory on economic development', Journal of World Business, 44, 2, pp. $131-143$.

Buckley, P. J. (2010). 'The role of headquarters in the global factory'. In U. Andersson and U. Holm (eds), Managing the Contemporary Multinational, pp. 60-84. Cheltenham, Edward Elgar.

Buckley, P. J. (2011a). Globalization and the Global Factory. Cheltenham: Edward Elgar. 
Buckley P. J. (2011b). 'International integration and coordination in the global factory', Management International Review, 51, 2, pp. 269-283.

Buckley, P. J. (2012). 'The Multinational Enterprise as a Global Factory'. In A. Verbeke and H. Merchant (eds), Handbook of Research on International Strategic Management, pp. 77-92.

Cheltenham: Edward Elgar.

Buckley, P. J., and M. C. Casson (1976). The Future of the Multinational Enterprise. London: Macmillan [25 $5^{\text {th }}$ Anniversary edition, 2001].

Buckley, P. J., and M. C. Casson (1985). Economic Theory of the Multinational Enterprise. London: Macmillan.

Buckley, P. J., and M. C. Casson (1988). 'A Theory of Cooperation in International Business'. In F. J. Contractor and P. Lorange (eds), Cooperative Strategies in International Business. Lexington MA. Lexington Books, D. C. Heath \& Co.

Buckley, P. J., and M. C. Casson (1998a). 'Models of the multinational enterprise', Journal of International Business Studies, 29, 1, pp. 21-44.

Buckley, P. J., and M. C. Casson (1998b). 'Analysing foreign market entry strategies: Extending the internalization approach', Journal of International Business Studies, 2, 3, pp. 539-561. 
Buckley, P. J., and M. C. Casson (2007). 'Edith Penrose's Theory of the Growth of the Firm and the strategic management of multinational enterprises', Management International Review, 47, 2, pp. 151173.

Buckley, P. J., and M. C. Casson (2009). 'The internalization theory of the multinational enterprise: A review of the progress of a research agenda after 30 years', Journal of International Business Studies, 40, pp. $1563-1580$.

Buckley, P. J., and M. C. Casson (2011). 'Marketing and the multinational', Journal of the Academy of Marketing Science, 39, 2, pp. 492-508.

Buckley, P. J., J. Clegg, A. Cross, P. Zheng, H. Voss and X. Liu (2007). 'The determinants of Chinese outward foreign direct investment', Journal of International Business Studies, 38, 4, pp. 499 - 518.

Buckley, P. J., T. M. Devinney, and J. J. Louviere (2007). 'Do managers behave the way theory suggests? A choice theoretic examination of foreign direct investment location decision making', Journal of International Business Studies, 38, 7, pp. 1069-1094.

Buckley, P. J., J. Doh, and M. Benischke 2017. 'Towards a Renaissance in International Business Research? Big Questions, Grand Challenges and the Future of IB Scholarship', Journal of International Business, 48, 9, pp. 1045-1064

Buckley, P. J., P. N. and Ghauri (2004). 'Globalisation, Economic Geography and the Strategy of Multinational Enterprises', Journal of International Business Studies, 35, 2, pp. 81-98.

Buckley P. J., and N. Hashai (2004). ‘A global system view of firm boundaries', Journal of International Business Studies, 35, 1, pp. 33-45. 
Buckley P. J., and D. R. Lessard (2005). 'Regaining the edge for international business research', Journal of International Business Studies, 36, pp. 595-599.

Buckley, P. J. \& R. Strange (2015). 'The Governance of the Global Factory: Location and Control of World Economic Activity’, Academy of Management Perspectives, 29, 2, pp 237-249.

Cantwell, J. A. (2014). 'Revisiting international business theory: A capabilities-based theory of the MNE', Journal of International Business Studies, 45, pp. 1-7.

Casson, M. C. (1996). 'The nature of the firm reconsidered: Information synthesis and entrepreneurial organization', Management International Review, 36, 1, pp. 55-94.

Casson, M. C. (1997). Information and Organization. Oxford: Oxford University Press.

Casson, M. C. (1982). The Entrepreneur: An Economic Theory. New ed. 2003. Cheltenham: Edward Elgar.

Casson, M. C. (1990). Enterprise and Competitiveness. Oxford: Clarendon Press.

Casson, M. C. (2000). Economics of International Business: A New Research Agenda. Cheltenham: Edward Elgar.

Casson, M. C. (2005). 'Visions of International Business'. In P. J. Buckley (ed.), What is International Business? Basingstoke: Palgrave Macmillan.

Casson, M. C. (2014). 'The economic theory of the firm as a foundation for international business theory', Multinational Business Review, 22, 3, pp. 205-226. 
Casson, M. C. (2014). 'Coase and international business: the origin and development of internalisation theory', Managerial and Decision Economics, 36, 1, pp. 55-66.

Casson, M. C. (2016). The Theory of International Business: Economic Models and Methods. London: Palgrave Macmillan.

Casson, M. C., K. R. Dark and M. A. Gulamhussen (2009). 'Extending internalisation theory: From the multinational enterprise to the knowledge-based empire', International Business Review, 18, pp. 236-256.

Casson, M. C., and N. S. Wadeson (2012). 'The economic theory of international business: A supply chain perspective', Multinational Business Review, 20, 2, pp. 114-134.

Chandler, A. D. (1962). Strategy and Structure: Chapters in the History of the American Industrial Enterprise. Cambridge Mass: MIT Press.

Chen, W. and F. Kamal (2016). 'The impact of information and communications technology adoption on multinational firm boundary decisions'. Journal of International Business Studies. 47, 5, pp. 563576.

Coase, R. H. (1937). ‘The nature of the firm’, Economica (New Series), 4, pp. 387-405.

Collis, D., D. Young and M. Gould, (2007). 'The size, structure and performance of corporate headquarters', Strategic Management Journal, 28, 4, pp. 383-405.

Deeg, R. and G. Jackson (2008). 'Comparing capitalisms: understanding institutional diversity and its implications for international business'. Journal of International Business Studies, 39, 4, pp 540-561. 
Dunning, J. H. (1958). American Investment in British Manufacturing Industry. London: Allen \& Unwin.

Dunning, J. H. (1977). ‘Trade, location of economic activity and multinational enterprise: A search for an eclectic approach'. In B. Ohlin, P. O. Hesselborn and P. M. Wijkman (eds), The International Allocation of Economic Activity, pp. 395-418. London: Macmillan.

Dunning, J. H. (1983). 'Changes in the level and structure of international production: the last one hundred years'. In M. C. Casson, (ed), The Growth of International Business, pp. 84-139. London: Allen \& Unwin.

Dunning, J. H. (1993). 'Internationalising Porter's Diamond', Management International Review, 33, 2, pp. 7-15.

Dunning, J. H., and S. M. Lundan (2008). Multinational Enterprises and the Global Economy. Second edition. Cheltenham: Edward Elgar.

Foss, N. J. (1977). 'On the rationales of corporate headquarters', Industrial and Corporate Change, 6, 2, pp. 313-338.

Fudenberg, D. and J. Tirole (1991). Game Theory. Cambridge: MIT Press.

Graham, E. M. (1978). 'Transnational investment by multinational firms: A rivalistic phenomenon', Journal of Post-Keynesian Economics, 1, pp. 82-99.

Granstrand, O. (1998). 'Towards a theory of the technology-based firm'. Research Policy, 27, 5, pp 465-489. 
Harrigan, K. R. (1985). ‘An application of clustering for strategic group analysis', Strategic Management Journal, 6, 1, pp. 55-73.

Hennart, J-F. (1982). A Theory of Multinational Enterprise. Ann Arbor: University of Michigan.

Hennart J-F. (2009). 'Down with MNE-centric theories! Market entry and expansion as the bundling of MNE and local assets', Journal of International Business Studies, 40, 9, pp. 1432-1454.

Hoskisson, R. E., M. Wright, I. Filatotchev and M. W. Peng (2013). 'Emerging multinationals from mid-range economies: The influence of institutions and factor markets', Journal of Management Studies, 5, 7, pp. 1295-1321.

Hymer, S. H. (1976). The National Operations of International Firms, [MIT PhD dissertation, 1960]. Cambridge, MA: MIT Press.

Kirzner, I. M. (1973). Competition and Entrepreneurship. Chicago: University of Chicago Press.

Knickerbocker, F. T. (1973). Oligopolistic Reaction and Multinational Enterprise. Cambridge MA: Harvard University Press.

Knight, F. H. (1921). Risk Uncertainty and Profit. Boston: Houghton Mifflin.

Krugman, P. R. (1991). Geography and Trade. Cambridge, MA: MIT Press.

Kunisch, S., M. Menz, and B. Ambos (2015). 'Changes at Corporate Headquarters: Review Integration and Future Research', International Journal of Management Reviews, 17, 3, pp. 356-381. 
Leamer, E. E. and M. Storper (2001). 'The economic geography of the internet age', Journal of International Business Studies, 32, 4, pp. 641-665.

Markusen, J. R. (2002). Multinational Firms and the Theory of International Trade. Cambridge, MA: MIT Press.

Martin, J. A., and K. M. Eisenhardt (2010). 'Rewiring: Cross Business-Unit Collaborations and Performance in Multi-Business Organizations', Academy of Management Journal, 53, 2, pp. 265-301.

Menz, M., S. Kunisch and D. Collis (2015). 'The Corporate Headquarters in the Contemporary Corporation', Academy of Management Annals, 9, 1, pp. 633-714.

McManus. J. C. (1973). 'The theory of the international firm'. In G. Paquet (ed), The Multinational Firm and the Nation State, Toronto: Collier Macmillan, 66-93, reprinted in Mark Casson (ed), Multinational Corporations, pp. 32-59. Aldershot: Edward Elgar, 1990.

McManus, J. C. (1975). 'The cost of alternative economic organizations', Canadian Journal of Economics, 8, pp. 334-350.

Oxley, J. E. and B. Yeung (2001). 'E-commerce readiness: institutional, environmental and international competitiveness', Journal of International Business Studies. 32, 4, pp. 705-723.

Penrose, E. T. (1959). Theory of the Growth of the Firm. Oxford: Blackwell.

Petit, M. L., and F. Sanna-Randaccio (2000). 'Endogenous R\&D and foreign direct investment in international oligopolies', International Journal of Industrial Organization, 18, pp. 339-367. 
Petit, M. L., F. Sanna-Randaccio, and R. Sestini (2012). 'R\&D and foreign direct investment with asymmetric spill-overs', Economics of Innovation and New Technology, 21, 2, pp. 125-150.

Porter, M. E. (1980). Competitive Advantage. New York: Free Press.

Ramamurti, R. (2012). 'What is really different about emerging market multinationals?', Global Strategy Journal, 2, 1, pp. 41-47.

Ramamurti, R. and J. Singh (Eds). (2009). Emerging Multinationals in Emerging Markets. Cambridge: Cambridge University Press.

Richardson, G. B. (1964). Economic Theory. London: Hutchison (reprinted Routledge, 2003).

Richardson, G. B. (1998). The Economics of Imperfect Knowledge: Collected Papers. Cheltenham: Edward Elgar.

Robbins, L. (1932). An Essay on the Nature and Significance of Economic Science. London: Macmillan.

Rowthorn, R., and S. H. Hymer (1971). International Big Business. Cambridge: Cambridge University Press.

Rugman, A. M. (1981). [2006] Inside the Multinationals: The Economics of Internal Markets. London: Croom Helm, [Basingstoke: Palgrave Macmillan].

Rugman, A. M., and J. R. D’Cruz (2000). Multinationals as Flagship Firms: Regional Business Networks. Oxford: Oxford University Press. 
Rugman, A. M., and A. Verbeke (2001). 'Subsidiary - Advantages in Multinational Enterprises', Strategic Management Journal, 22, 3, pp. 237-250.

Rugman, A. M., and A. Verbeke (2003). 'Extending the theory of the multinational enterprises: Internalization theory and strategic management perspectives', Journal of International Business Studies, 34, 2, pp. 125-137.

Rugman, A. M. and A. Verbeke (2004). 'A perspective on regional and global strategies of multinational enterprises', Journal of International Business Studies, 35, 1, pp. 3-18.

Samuelson, P. A. (1947). Foundations of Economic Analysis. Cambridge, MA: Harvard University Press.

Sanna-Randaccio, F. and R. Veugelers (2007). 'Multinational knowledge spill-overs with decentralised R\&D: A game-theoretic approach', Journal of International Business Studies, 38, pp. 4763.

Schumpeter, J. A. (1934). Theory of Economic Development (trans R. Opie). Cambridge, MA: Harvard University Press.

Wilkins, M. (1988). 'The free-standing company, 1870-1914: An important type of British foreign direct investment', Economic History Review, 41, 2, pp. 259-282.

Williamson, O. E. (1975). Markets and Hierarchies: Analysis and Anti-trust Implications. New York: Free Press. 